\title{
THE AGE OF THE SOKLI CARBONATITE, FINLAND, AND SOME RELATIONSHIPS OF THE NORTH ATLANTIC ALKALINE IGNEOUS PROVINCE
}

\author{
H. Vartiainen and A. R. Woolley
}

Vartiainen, H. and Woolley, A. R. 1974: The age of the Sokli carbonatite, Finland, and some relationships of the North Atlantic alkaline igneous province.

Bull. Geol. Soc. Finland 46, 81-91.

Nine dates from the Sokli area are presented, including four not previously published. Dates of the carbonatite range from 334 to 392 my. with one markedly discordant date of 247 my. Fenites give dates ranging from $354 \pm 19 \mathrm{my}$, close to the carbonatite contact, to $488 \pm 18$ and $1220 \pm 40$ my. at approximately one kilometre from the contact. Unfenitized basement granite and syenite are dated at $1760 \pm 30$ and $1740 \pm 35$ my. A summary is presented of the spatial and temporal relationships of the carbonatites and alkaline complexes of the North Atlantic alkaline igneous province as defined by Doig (1970), for which there are now available some 50 isotopic dates. These fall into three main groups which correspond closely in time with the peaks of the Caledonian - Appalachian, Grenville, and Hudsonian - Svecokarelian orogenic episodes. All three groups are represented in Canada and Europe, and two of them in Greenland. It is pointed out that in addition to the carbonatites, most of the world's described alkaline complexes which are layered occur within the province. The correspondence between the ages of emplacement of the igneous intrusions and the orogenic episodes is ascribed to deep tensional faulting in the forelands caused by down buckling of crustal plates along the orogenically active zones. The production of carbonatite magma and layered alkaline igneous complexes in this relatively narrow zone, and over a time span of $2000 \mathrm{my}$. during which there was presumably differential motion between crustal plates and mantle, suggests that the lithosphere probably played an important role in the production of these exotic igneous rocks.

H. Vartiainen, Rautaruukki Oy, 96200 Rovaniemi 20, Finland.

A. R. Woolley, Department of Mineralogy, British Museum (Natural History), Cromwell Road, London SW7, England. 


\section{The age of the Sokli intrusion}

The Sok li carbonatite intrusion was discovered by airborne geophysical survey in 1967 in the course of an extensive search for alkaline rocks in NE Finland carried out by the steel company Rautaruukki Oy. A drilling and trenching programme has indicated that the carbonatite intrusion occupies an area of more than $20 \mathrm{~km}^{2}$, which makes it one of the biggest, if not the biggest, carbonatite so far discovered.

Nine age determinations have been made on rocks from the Sokli area (Fig. 1), and are given in Table 1. The first three determinations listed in Table 1 were briefly referred to in a footnote by Paarma (1970) and Kononova and Shanin (1973) have published the ages determined by them. Apart from one markedly discordant date of $247 \mathrm{my}$. the dates determined on minerals from the carbonatite lie within the range 334 to 392 my., indicating a probable age of emplacement of the carbonatite of about $360 \mathrm{my}$. ie Upper Devonian. Dr Kouvo (personal communication) is not sure of the reason for the discordant 247 my. date, but thinks it may be due to some intrinsic property of the pyrochlore.

It is apparent from Fig. 3 that Sokli comprises part of the extensive Kola Peninsula carbonatite-

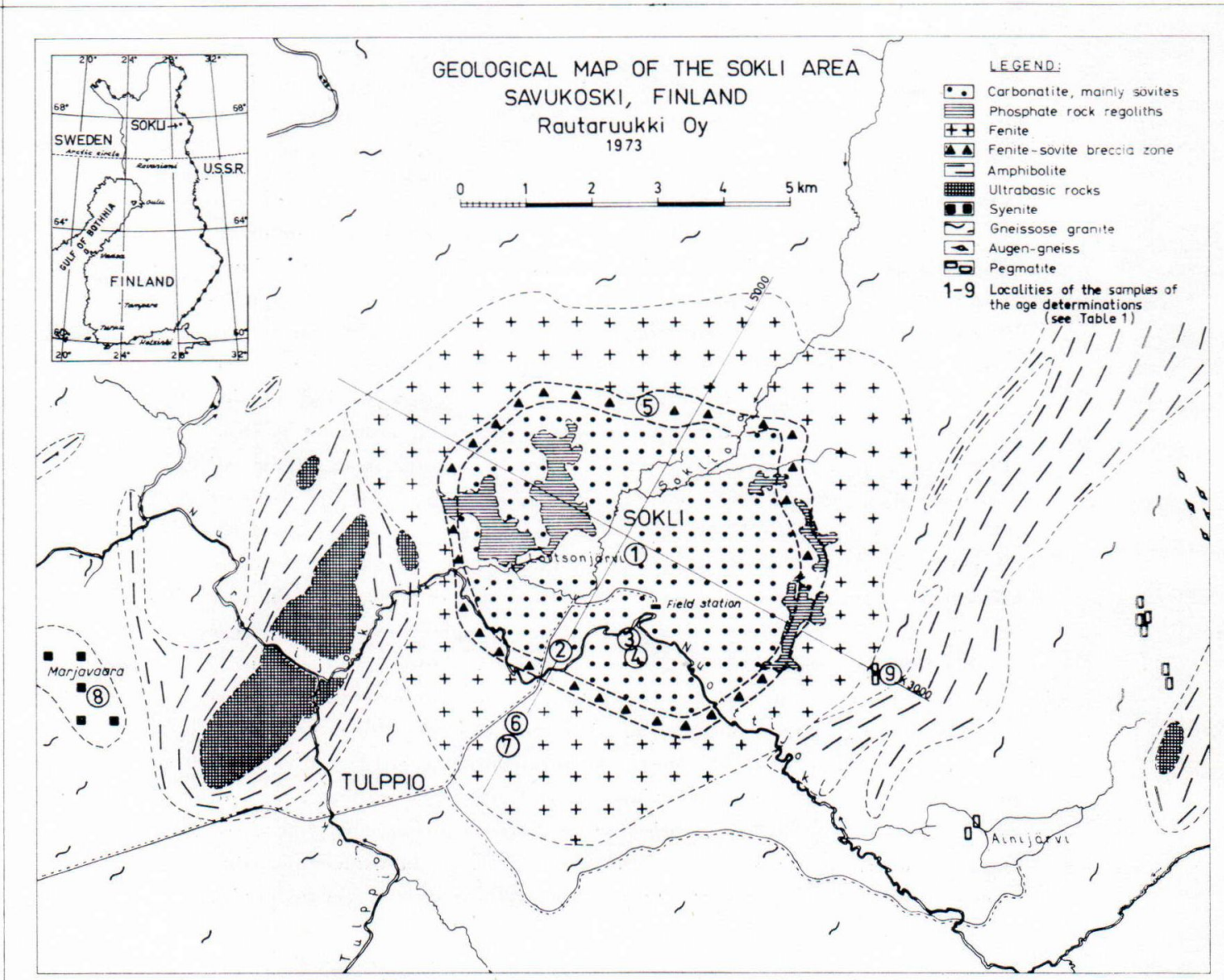

Fig. 1. Geological map of the Sokli area showing the location of dated specimens. 
TABle 1

Age determinations from the Sokli area

\begin{tabular}{|c|c|c|c|c|c|c|c|}
\hline rock type & $\begin{array}{l}\text { localities } \\
\text { (fig. 1) }\end{array}$ & mineral & method & age (m.y.) & \multicolumn{3}{|c|}{ analyst } \\
\hline \multirow[t]{8}{*}{ CARBONATITE } & \multirow[t]{4}{*}{1} & \multirow[t]{4}{*}{ Pyrochlore } & $\begin{array}{l}\text { U-Th-Pb } \\
206 / 238\end{array}$ & 347 & \multicolumn{3}{|l|}{ Kouvo $^{1}$} \\
\hline & & & $207 / 235$ & 334 & & & \\
\hline & & & $207 / 206$ & 247 & & & \\
\hline & & & $208 / 232$ & 378 & & & \\
\hline & 2 & Phlogopite & $\mathrm{Rb} / \mathrm{Sr}$ & $355 \pm 10$ & \multicolumn{3}{|l|}{ Sakko $^{1}$} \\
\hline & 3 & Phlogopite & $\mathrm{K} / \mathrm{Ar}$ & $350 \pm 10$ & \multicolumn{3}{|l|}{ Snelling ${ }^{2}$} \\
\hline & 4 & Phlogopite & $\mathrm{K} / \mathrm{Ar}$ & $392 \pm 12$ & \multicolumn{3}{|c|}{ Kononova et al. (1973) } \\
\hline & & & & $390 \pm 12$ & & & \\
\hline \multicolumn{8}{|l|}{ FENITE } \\
\hline $\begin{array}{l}\text { Phlogopite-alkaline-amphibole syenitic } \\
\text { fenite } \ldots \ldots \ldots \ldots \ldots \ldots \ldots \ldots \ldots \ldots \ldots \ldots \ldots\end{array}$ & 5 & Amphibole & $\mathrm{K} / \mathrm{A}$ & $354 \pm 19$ & $"$ & $» »$ & $"$ \\
\hline Aegirine syenitic fenite $\ldots \ldots \ldots \ldots \ldots \ldots$ & 6 & Whole rock & $\mathrm{K} / \mathrm{A}$ & $488 \pm 18$ & $"$ & $" »$ & $"$ \\
\hline Aegirine-alkaline-amphibole syenitic fenite & 7 & Amphibole & $\mathrm{K} / \mathrm{A}$ & $1220 \pm 40$ & $»$ & $» »$ & $»$ \\
\hline \multicolumn{8}{|l|}{ COUNTRY ROCKS } \\
\hline Syenite ......... & 8 & Amphibole & $\mathrm{K} / \mathrm{A}$ & $1740 \pm 35$ & \multicolumn{3}{|l|}{ Snelling } \\
\hline Gneissose granite. & 9 & Biotite & $\mathrm{K} / \mathrm{A}$ & $1760 \pm 30$ & \multicolumn{3}{|c|}{ Kononova et al. (1973) } \\
\hline
\end{tabular}

1) Dr O. Kouvo and Dr M. Sakko, Geological Survey of Finland.

2) Dr N. J. Snelling, Institute of Geological Sciences, London.

alkaline igneous province, the Kovdor carbonatite lying only some $60 \mathrm{~km}$ ESE of Sokli. Seven Kola carbonatites have been dated (Table 2), and they all fall within the range 344 to $410 \mathrm{my}$, which confirms the temporal, as well as spatial relationship of Sokli to the Kola province. The Iivaara complex, although a little older at 430 my. (Doig 1970), is also part of the province.

The rocks in the vicinity of the Sokli intrusion are shown on the geological map of Finland (Simonen, 1960) to be part of the pre-Karelian granite gneiss basement, which gives dates of the order of 2600 to $2800 \mathrm{my}$. (Kouvo and Tilton, 1966). However it is pointed out by Kouvo and
Tilton (1966) that although zircons from preKarelian rocks usually give dates in the range $2600-2800$ my., measurements by the K-Ar method, and work on micas, give younger dates of about $1750-1850 \mathrm{my}$. which reflect a later period of regional metamorphism.

Two age determinations have been made on basement rocks from the Sokli area, both by the $\mathrm{K}$-Ar method; one on a biotite from a gneissose granite, and the other on an amphibole from the Marjavaara syenite intrusion which lies $5 \mathrm{~km}$ to the west of Sokli (Fig. 1 and Table 1). The granite biotite gives a date of $1760 \pm 30$ my., which is probably the age of the last regional 
TABLE 2

Ages of carbonatites and alkaline complexes in northwestern Europe, Greenland and Canada

Caledonian - Appalachian

\begin{tabular}{|c|c|c|c|c|}
\hline EUROPE & $\begin{array}{l}1 \text { Kontozero } \\
2 \text { Lovozero } \\
3 \text { Khibina } \\
4 \text { Sebljavrsk } \\
5 \text { Ozernaya Veraka } \\
6 \text { Salmogorsk } \\
7 \text { Afrikanda } \\
8 \text { Turyi } \\
9 \text { Gornoozersk } \\
10 \text { Vuorijarvi } \\
11 \text { Kovdor } \\
12 \text { Sokli } \\
13 \text { Iivaara } \\
14 \text { Sørøy } \\
15 \text { Alnö } \\
16 \text { Fen } \\
17 \text { Borralan }\end{array}$ & $\begin{array}{l}410 \\
386-422 \\
392-430 \\
383 \\
365-400 \\
480-540 \\
344-426 \\
363 \\
392-540 \\
380-402 \\
370 \\
334-378 \\
430 \\
384-420 \\
563 \\
565 \\
388\end{array}$ & 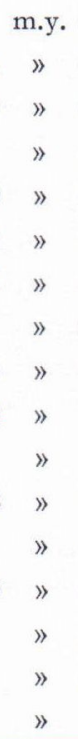 & $\begin{array}{l}\text { (Polkanov and Gerling 1961) } \\
\text { (Kononova and Shanin 1972) } \\
\text { (Kononova and Shanin 1972) } \\
\text { (Kukharenko 1965) } \\
\text { (Kukharenko 1967) } \\
\text { (Kononova and Shanin 1972) } \\
\text { (Kukharenko 1967i } \\
\text { (Doig 1970) } \\
\text { (Kononova and Shanin 1972) } \\
\text { (Kukharenko 1967) } \\
\text { ( } ~ \\
\text { (This paper) } \\
\text { (Doig 1970) } \\
\text { (Sturt et al. 1967) } \\
\text { (von Eckermann and Wickman 1956) } \\
\text { (Faul et al. 1959) } \\
\text { (Brown et al. 1968) }\end{array}$ \\
\hline $\begin{array}{l}\text { GREENLAND } \\
\begin{array}{ll}24 \text { Kangerdlugssuaq } 52 \mathrm{~m} . \mathrm{y} . & \text { (Wager } \\
& \text { and } \\
& \text { Brown } \\
& 1968 \text { ) }\end{array}\end{array}$ & 25 Umanak & 600 & m.y. & (Larsen and Møller 1968) \\
\hline $\begin{array}{l}\text { CANADA } \\
29 \text { Oka } \\
\begin{array}{ll} & \\
& \\
& \\
& \text { bairn } \\
& \text { et al. } \\
& 1963 \text { ) }\end{array}\end{array}$ & $\begin{array}{l}30 \text { Aillik } \\
31 \text { Mutton Bay } \\
32 \text { Chicoutimi } \\
33 \text { Eastview } \\
34 \text { Brent } \\
35 \text { Callander Bay } \\
36 \text { Manitou Island } \\
37 \text { Burritt Island } \\
38 \text { Iron Island }\end{array}$ & $\begin{array}{l}570 \\
568 \\
564 \\
320 \\
560 \\
560 \\
560 \\
560 \\
560\end{array}$ & $\begin{array}{c}\text { m.y. } \\
» \\
» \\
» \\
» \\
» \\
» \\
»\end{array}$ & 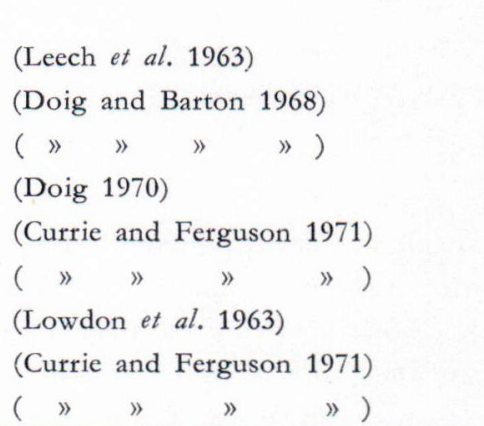 \\
\hline
\end{tabular}

metamorphism. The amphibole from the syenite gives a date of $1740 \pm 35$ my. which may also be a metamorphic age, but it is more likely to be the age of intrusion of the syenite. Whichever interpretation is correct the date indicates that the Marjavaara syenite does not comprise part of the Kola carbonatite-alkaline igneous province, but rather is probably part of the syntec- tonic plutonic episode which was widespread in Finland about 1800 to 1900 my. ago (Kouvo and Tilton, 1966).

Around the Sokli intrusion there is a broad metasomatic aureole of fenitization which extends up to $2.5 \mathrm{~km}$ from the carbonatite contact (Fig. 1). In the outer part of the aureole the fenitization effects are slight, and it is only in the 


\section{Grenville}

18 Norra Kärr
1020 m.y. (von Eckermann 1968)
Hudsonian - Svecokarelian

\begin{tabular}{|c|c|c|}
\hline 19 Almunge & 1580 & m.y. (Doig 1970) \\
\hline 20 Siilinjärvi & $1785-2030$ & » (Puustinen 1972) \\
\hline 2.1 Laivajoki & 2020 & $(\text { Kouvo })^{1}$ \\
\hline $\begin{array}{l}22 \text { Gremyatkla- } \\
\text { Byrmes }\end{array}$ & $1750-1870$ & (Shanin et al. 1967) \\
\hline 23 Eletozero & 1800 & (Kukharenko 1969) \\
\hline
\end{tabular}

1) personal communication

\begin{tabular}{llll}
26 Ilimaussag & $1020 \mathrm{~m} . \mathrm{y}$. & (Moorbath et al. 1960) \\
27 Nunarssuit & 1128 (Bridgewater 1965) \\
28 Kungnat & $1170 \gg$ (Moorbath et al. 1960) \\
\hline
\end{tabular}

39 Seabrook Lake 1103 m.y. (Gittins et al. 1967)

40 Lackner Lake 1090 " (Lowdon et al. 1963)

41 Portage 1069 " (Gittins et al. 1967)

42 Nemegosenda >1010 ( " 》")

43 Firesand River 1048 » ( ” » 》)

44 Clay-Howells 1010 " ( " " ")

45 Prairie Lake 1112 " ( " 》 》)

46 Big Beaver House 1005 ( 》 》» 》)

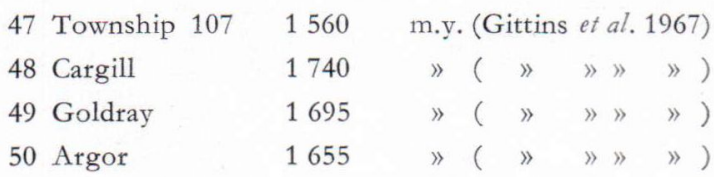

inner few hundred metres of the aureole that the last vestiges of the primary minerals and structures of the basement gneisses and schists are completely destroyed and replaced by new ones. In such a geological environment, and assuming that the fenitization was caused by the carbonatite and so should have the same age, one would expect a spectrum of dates, depending on the extent to which the fenites were equilibrated by the fenitization process, ranging from young dates in the inner part of the aureole, akin to those of the carbonatite itself, to basement dates in the outer part of the aureole.

Dating of the fenites by the $\mathrm{K} / \mathrm{A}$ method on two amphiboles and one whole rock has given dates of $354 \pm 19,488 \pm 18$ and $1220 \pm 40$ 
my. (Table 1, 5-7). The specimen giving the $354 \pm 19$ my. date comes from a fenite fragment encountered in a drill hole through a zone of brecciated fenite close to the carbonatite contact, and is of a type characteristic of the inner part of the Sokli fenite aureole, comprising almost solely a brown phlogopite and a blue alkaline amphibole; the amphibole was dated. As this date is closely comparable to the age of the carbonatite itself, and was obtained from a rock from the innermost part of the fenite aureole, it is likely to be a true age.

Specimens 6 and 7 (Table 1) were both taken from cores from the same drill hole one kilometre from the carbonatite contact (Fig. 1), at depths of 69.80 to 70.00 metres and 177.40 to 177.50 metres respectively. Specimen 6 is an aegirine syenitic fenite and gave a date of 488 $\pm 18 \mathrm{my}$. on a whole rock sample, while specimen 7 is an aegirine-alkaline-amphibole syenitic fenite and the amphibole gave a date of $1200 \pm$ 40 my. (Table 1). These older dates suggest that these fenites, located further from the carbonatite contact than specimen 5 , represent country rocks which were not fully equilibrated by the fenitization process. A study of a large number of thin sections of Sokli fenites indicates that although there is a general increase in the degree of fenitization as the carbonatite is approached the increase is a very uneven one, so that commonly rocks which are closely juxtaposed in the field show widely differing degrees of fenitization. It is this uneveness of fenitization, and hence presumably of degree of equilibration, which probably accounts for the big difference in ages of two specimens from the same drill hole.

\section{The North Atlantic Alkaline Igneous Province}

It was shown by Gittins et al. (1967) that the carbonatite intrusions of Eastern Canada fall into four age groups at about 125 my., 565 my., 1075 my. and 1700 my., with a possible fifth at 1560 my. Doig (1970) indicated that the 565 my. group is also represented in Europe and he suggested, using a precontinental drift model, the presence of a very extensive and complex rift system extending from Eastern Canada to the Kola Peninsula and linking what he called the "North Atlantic alkaline igneous province».

There are now available some 50 isotopic age determinations on Canadian, European, and Greenland carbonatite and alkaline igneous complexes, and these substantiate the grouping of Gittins et al. (1967) for Canada and show that the three main groups are also represented in Europe. The dates are given in Table 2. Although Doig (1970) also used dates on kimberlites, gabbros, syenites, granites, and a lamprophyre in defining his alkaline province, the data given here are confined to carbonatites and peralkaline igneous intrusions, most of which are layered. The reason for including the alkaline complexes is that in the North Atlantic province, as elsewhere, they are often manifestly closely related to the carbonatite activity and the close association of carbonatites with alkaline igneous rocks can be demonstrated from many localities around the world. The Grønnedal-Ika carbonatite of Greenland (Emeleus 1964), for instance, is intruded into a layered sequence of nepheline syenites and syenites, while the Lovozero and Khibina layered alkaline igneous intrusions are spatially and temporally part of the Kola carbonatite province. The Kangerdlugssuaq syenitenepheline syenite intrusion of east Greenland (Kempe, Deer and Wager, 1970), and the Borralan Complex, Scotland (Woolley, 1973) are also included because of their strongly alkaline compositions; both complexes are also layered. The Lackner intrusion of Ontario, Canada (Parsons 1961) contains a layered sequence of alkaline rocks as well as carbonatite.

The layered alkaline intrusions all lie within a relatively narrow zone which extends from Ontario through Greenland and Scotland to the Kola peninsula, and which includes most of the World's described layered complexes of alkaline 
type; indeed, all the layered intrusions of alkaline type referred to in Wager and Brown's book (1968) on »Layered igneous rocks», lie within this zone. It is also perhaps significant that numerous layered intrusions which are not of alkaline type also lie along this zone, notably Skaergaard, Kap Edvard Holm, Kaerven, and Lilloise in east Greenland, Rhum and Cuillin in Scotland, and Bay of Islands and Kiglapait in Canada.

Also included in Table 2 is the Iivaara intrusion of Finland which is composed dominantly of ijolite and stongly fenitizes the surrounding rocks. The Norra Kärr and Almunge intrusions of Sweden do not show gravity layering but are both strongly alkaline, have fenite envelopes, and must be considered as members of the province.

The grouping of dates is illustrated by the histogram (Fig. 2 a) which shows that, apart from the two youngest dates, carbonatitic and alkaline igneous activity falls into three principal groups each of which extends over some 300 my., and each of which is separated by about the same time span. European and Canadian dates fall into each group, but no intrusions of the oldest group have yet been recognised from Greenland. Also shown on Fig. 2(b) are some frequency distribution curves for isotopic age determinations from the North Atlantic area to show the main Caledonian-Appalachian, Grenville, and Hudsonian-Svecokarelian orogenic events. It is apparent that there is a close correlation of the carbonatite-alkaline igneous activity with the three orogenies, and Gittins et al. (1967) pointed out that their $1000-1100 \mathrm{my}$. and $1650-1750$ my. groups corresponded in age to the Grenville and the Churchill (Hudsonian) Provinces. The oldest group of carbonatites closely correlates with the main phase of the Hudsonian-Svecokarelian orogeny, but the second group clusters just before the peak of the Grenville. The intrusions corresponding to the Caledonian-Appalachian event are split into two groups with the majority of Canadian occurrences being somewhat older

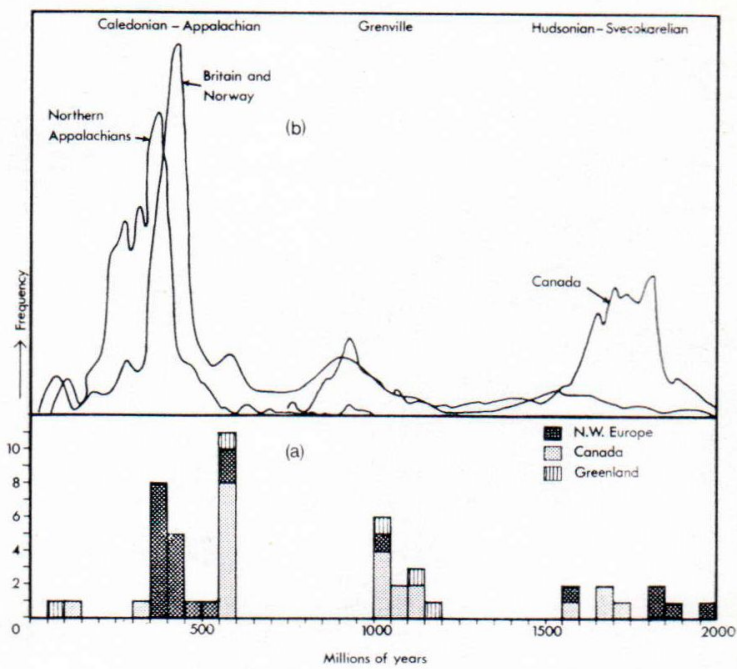

Fig. 2. (a) Histogram of dates given in Table 2. (b) Frequency distribution curves for parts of the North Atlantic area to show the principal orogenic events, the correlation of which with the principal concentrations of dates of carbonatites and alkaline igneous intrusions from the North Atlantic alkaline igneous province is apparent. Data taken from Sabine and Watson (1971) and Brock (1964) for Britain and Norway; Lyons and Faul (1968) for the Northern Appalachians; and Stockwell (1964) for Canada. The vertical scale is not the same for each curve.

The horizontal scales for (a) and (b) are the same.

than the European, and emplaced just prior to the main orogeny, while the emplacement of the European intrusions appear to coincide with the peak of Caledonian orogenic activity.

The distribution of intrusions of the North Atlantic alkaline igneous is shown on Fig. 3 on a pre-continental drift reconstruction based on that of Bullard et al. (1965). The areas affected by the Caledonian-Appalachian, Grenville, and Hudsonian-Svecokarelian orogenies are indicated. If the carbonatites and alkaline intrusions of Caledonian-Appalachian age are considered, they can be seen to have been emplaced in a zone parallel to the main fold belt, and within a few hundred kilometres of it; the only exception is the Umanak carbonatite of West Greenland. A number of the intrusions occur very close to the Caledonian-Appalachian front notably the East- 


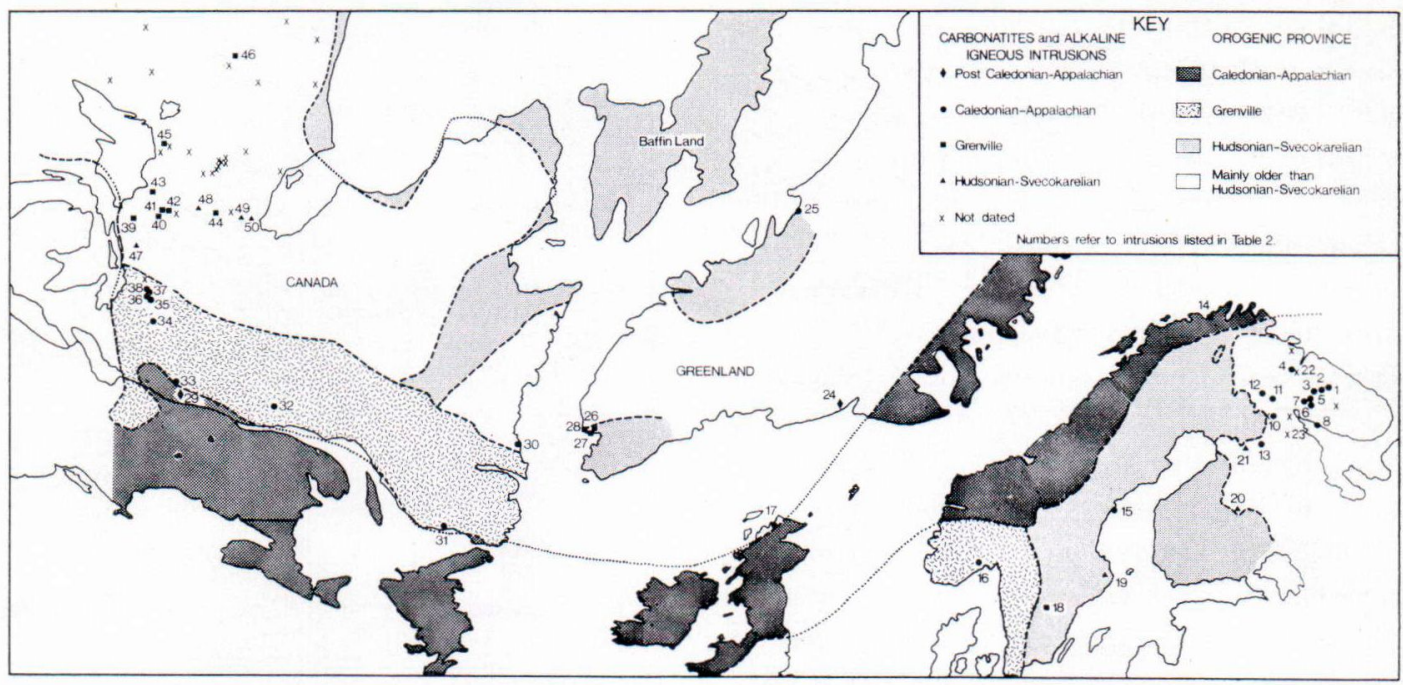

Fig. 3. Map of the North Atlantic area based on the precontinental drift reconstruction of Bullard et al. (1965). The principal orogenic provinces are shaded, and the carbonatite and alkaline igneous intrusions comprising the North Atlantic alkaline igneous province are shown. The numbered intrusions are those for which dates are available, as given in Table 2.

view, Chicoutimi, and Mutton Bay carbonatites in Canada, and the Borralan Complex in Scotland, the latter coming within 200 metres of the Moine Thrust which marks the edge of the Caledonian belt in this area. The Stjernøy-Sørøy carbonatite-alkaline igneous complex of northern Norway appears to be unique in its emplacement within the orogenic belt.

The intrusions of Grenville age lie outside the Grenville belt, but rather close to it, notably Norra Kärr in Sweden, the Gardar intrusions of Greenland, and many of the carbonatites in Ontario. An obvious exception is the Big Beaver House carbonatite in Ontario, which lies a considerable distance away from the Grenville belt.

The oldest group of carbonatites in Canada are all emplaced within very old basement rocks of the Superior Province, and can be considered as marginal to the Hudsonian Orogenic belt of the Churchill Province (Fig. 3). Similarly the Siilinjärvi carbonatite of Finland is intruded into ancient Pre-Karelian granites and gneisses (Puustinen 1971) as is the recently discovered Laivajoki dolomitic carbonatite. The Almunge Complex of
Sweden however, is of late Svecokarelian age and is emplaced in Svecokarelian gneisses and granites (Gorbatschev 1960). The paucity of dates of these oldest intrusions and the complexity of the rocks into which they were emplaced makes it difficult to make out any particular spatial relationship with confidence.

In summary, the evidence appears to suggest, firstly that there is a principal three-fold grouping of ages which corresponds rather closely with major orogenic episodes, and secondly that the intrusions of Caledonian-Appalachian age occur within a relatively narrow zone on either side of the orogenic belt, and this appears to hold for Grenville intrusions also.

Doig (1970) was able to make a good case for relating his $565 \mathrm{my}$. carbonatite-alkaline igneous intrusive event to a rift valley system in eastern Canada extending along the St Lawrence Valley with a branch extending to the Lake Nippissing area. However, the European sector of the province is not so amenable to such an interpretation, for although there are numerous fault systems to choose from, there is no obvious rift system to 
which the distribution of carbonatites and alkaline igneous intrusions can be related. The difficulties of the rift system hypothesis are compounded when Grenville and Hudsonian-Svecokarelian intrusions are considered; the numerous carbonatites of Ontario, in particular, appear not to be related to any linear patterns. Nevertheless, the association of carbonatites and many alkaline igneous intrusions with graben systems or major faults is apparent in many parts of the World, notably East Africa, but the outstanding feature linking the intrusions comprising the North Atlantic alkaline igneous province, it is suggested, is not a rift system, but the close temporal relationship to successive major orogenic events. It would seem possible to reconcile these relationships with faulting of an essentially tensional nature in terms of a plate tectonics model.

If it is assumed that the Caledonian-Appalachian and Grenville orogenic belts were located between two converging plates, then within the plates themselves, but outside the orogenically active area, deep faulting might be caused either by the plates being of "pulled» type, so that tension within the plate could lead to normal faulting, or there might be compensatory arching of the plate in a broad zone behind the down-buckled, leading plate edge, which could lead to fracturing of the arch, if not graben structures. In an ideal model of straight sided pulled or arched plates of homogeneous composition and equal thickness, one would expect a simple system of normal faults and perhaps graben to develop perpendicular to the direction of motion, in a zone on either side of the orogenic belt. A real situation of irregularly shaped and heterogeneous plates would be expected to result in a more complex and variable system. It is suggested that such a model might explain the principal temporal and spatial features of the North Atlantic alkaline igneous province, such that the orogenic episodes led to contemporaneous, but sporadic, deep faulting within the forelands, thus tapping relatively deep levels in the mantle, while the stable crustal con- ditions pertaining in these forelands allowed the production of highly differentiated alkaline magmas, including carbonatite, and the formation of layered complexes.

It is a remarkable, if not unique, feature of the North Atlantic alkaline igneous province that within this relatively restricted area of the Earth's crust there has been the successive production, over a period of nearly $2000 \mathrm{my}$, , of carbonatite magma, which is probably the most extremely differentiated of all igneous magmas, and layered alkaline complexes, which are singularly absent in other parts of the world. If it is assumed that there has been differential motion between crustal plates and the mantle in this area, then the unusual features of the magmatism cannot be attributed to local atypical mantle, or movement of plates over local »hot spots», but the lithosphere must have played a significant role in determining the nature of the igneous differentiation.

Acknowledgements - We are indebted to Dr H. Paarma of Rautaruukki Oy for giving permission to publish some of the isotopic dates. Miss V. Jones and Mrs R. Karila drew the diagrams. Dr J. Nuutilainen and Dr A. C. Bishop kindly read and made suggestions for the improvement of the manuscript which are gratefully acknowledged.

\section{REFERENCES}

BRIDGewater, D. (1965). Isotopic age determinations from South Greenland and their geological setting. Meddel. Grønland, 179, No. 4.

Broch, O. A. (1964). Age determination of Norwegian minerals up to March 1964. Norges Geol. Undersøkelse, 228, 84-113.

Brown, P. E., Miller, J. A. and Grasty, R. L. (1968). Isotopic ages of late Caledonian granitic intrusions in the British Isles. Proc. Yorks. Geol. Soc., 36, 251276.

Bullard, E. E., Everett, J. E. and Smith, A. G. (1965). The fit of the continents around the Atlantic. In A symposium on continental drift. Phil. Trans. Roy. Soc. London, 258 A, 41-51. 
Currie, K. L. and Ferguson, R. B. (1971). A study of fenitisation around the alkaline carbonatite complex at Callander Bay, Ontario, Canada. Can. J1. Earth Sci., $8,498-517$.

Dorg, R. (1970). An alkaline rock province linking Europe and North America. Can. J1. Earth Sci., 7, $22-28$.

- and Barton, J. M. (1968). Ages of carbonatites and other alkaline rocks in Quebec. Can. J1. Earth Sci., 5, $1401-1407$.

v. Eckermann, H. (1968). New contributions to the interpretation of the genesis of the Norra Kärr alkaline body in Southern Sweden. Lithos, 1, $76-88$.

- and Wickmann, F. E. (1956). A preliminary determination of the maximum age of the Alnö rocks. Geol. För. Stockh. Förh., 78, 122-124.

Emeleus, C. H. (1964). The Gronnedal - Ika alkaline complex, South Greenland. The structure and geological history of the complex. Meddel. Gronland, 172, No. 3.

Fairbairn, H. W., Faure, G., Pinson, W. H., Hurley, P. M. and Powell, J. L. (1963). Initial ratio of strontium 86 , whole-rock age, and discordant biotite in the Monteregian igneous provinces, Quebec. J. Geophys. Res., 68, 6515-6522.

Faul, H., Elmore, P. L. D. and Brannock, W. W. (1959). Age of the Fen carbonatite (Norway) and its relation to the intrusions of the Oslo region. Geochim. Cosmochim. Acta, 17, 153-155.

Ferguson, S. A. (1971). Columbium (niobium) deposits of Ontario. Ont. Dept. Mines and North. Affairs, Min. Res. Circular No. 14.

Gittins, J., Macintyre, R. M. and York, D. (1967). The ages of carbonatite complexes in eastern Canada. Can. J1. Earth Sci., 4, 651-655.

Gorbatschev, R. (1960). On the alkali rocks of Almunge. A preliminary report on a new survey. Bull. Geol. Inst. Univ. Uppsala (Minl.-Geol.), 39, 1-69.

- (1970). K-Ar age of biotite from the Almunge alkaline intrusion. Geol. För. Stockh. Förh., 92, 501-502.

Kempe, D. R. C., Deer, W. A. and Wager, L. R. (1970). Geological investigations in East Greenland. Part VIII. The petrology of the Kangerdlugssuaq alkaline intrusion, East Greenland. Meddel. Grønland, 190, No. 2 .

Kononova, V. A. and Shanin, L. L. (1972). On possible application of nepheline for alkaline rock dating. Bull. Volc. 35, 251-264.
- Shanin, L. L. and Rakelyants, M. M. (1973). Time of emplacement of alkaline complexes and carbonatites. (In Russian). Izvest. Akad. Nauk SSSR, Geol. Ser. No. 5.

Kouvo, O. and Tilton, G. R. (1966). Mineral ages from the Finnish Precambrian. Jour. Geology, 74, 421-442.

Kukharenko, A. A. (1967). Alkaline magmatic activity of the eastern part of the Baltic Shield. (In Russian). Zap. Vses. Mineral. Obsch., 96, 547-566.

Kunharenko, A. A. (Ed.) et al. (1965). The Caledonian complex of ultrabasics, alkali rocks and carbonatites in the Kola Peninsula and in North Karelia. Nedra, Moscow.

Kukharenko, A. A., Orlova, M. P. and Bagdasarov, E. A. (1969). Alkaline gabbros of Karelia. (In Russian). Izd. Leningr. Univ.

Larsen, O. and Møller, J. (1968). Potassium-argon age studies in West Greenland. Can. Jl. Earth Sci., 5, $683-691$.

Leech, G. B., Lowdon, J. A., Stockwell, C. H. and Wanless, R. K. (1963). Age determinations and geological studies. Geol. Surv. Canada, Report 4, Paper 63-17, 1-140.

Lyons, J. B. and Faul, H. (1968). Isotope geochronology of the Northern Appalachians. In Studies of Appalachian geology; Northern and Maritime. Edited by E-An Zen, W. S. White, J. B. Hadley and J. B. Thompson. Interscience Publishers, New York.

Moorbath, S., Webster, R. K. and Morgan, J. W. (1960). Absolute age determinations in South-West Greenland. Meddel. Grønland, 162, No. 9.

PaArma, H. (1970). A new find of carbonatite in North Finland, the Sokli Plug in Savukoski. Lithos, 3, 129 $-133$.

Parsons, G. E. (1961). Niobium-bearing complexes east of Lake Superior. Rep. Ont. Dept. Mines, 3, 1-73.

Polkanov, A. A. and Gerling, E. K. (1961). The PreCambrian geochronology of the Baltic Shield. Ann. New York. Sci., 91, 492-499.

Puustinen, K. (1971). Geology of the Siilinjärvi carbonatite complex, eastern Finland. Bull. Comm. Geol. Finlande, No. 249.

- (1972). Richterite and actinolite from the Siilinjärvi carbonatite complex, Finland. Bull. Geol. Soc. Finland, 44, 83-86.

Sabine, P. A. and Watson, J. V. (1971). Isotopic agedeterminations of rocks and minerals from the British Isles, 1967-8, with consolidated indexes for 195568. Quart. Jour. Geol. Soc. London, 126, 383-411. 
Shanin, L. L., Kononova, V. A. and Ivanov, I. B. (1967). On application of nepheline for $\mathrm{K}-\mathrm{Ar}$ geochronometry. Izvest. Akad. Nauk SSSR, Geol. Ser., No. 5. $19-30$.

Simonen, A. (1960). Pre-Quaternary rocks of Finland. Bull. Comm. Geol. Finlande, No. 191.

Stockwell, C. H. (1964). Fourth report on structural provinces, orogenies and time-classification of rocks of the Canadian Precambrian Shield. Geol. Surv. Canada, Paper 64-17 (pt. II).
Sturt, B. A., Mrller, J. A. and Fitch, F. J. (1967). The age of alkaline rocks from West Finnmark, Northern Norway, and their bearing on the dating of the Caledonian orogeny. Norsk. Geol. Tidsskr., 47, $255-273$.

WA Ger, L. R. and Brown, G. M. (1968). Layered igneous rocks. Oliver and Boyd, Edinburgh and London.

Woolley, A. R. (1973). The pseudoleucite borolanites and associated rocks of the South-Eastern Tract of the Borralan Complex, Scotland. Bull. Br. Mus. Nat. Hist. (Miner.), 2, 285-333. 